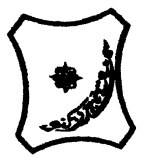

Bayero Journal of Pure and Applied Sciences, 12(1): 51 - 56

ISSN $2006-6996$

\title{
SPATIAL AND TEMPORAL PATTERNS OF PHYTOPLANKTON COMPOSITION IN ZOBE RESERVOIR, DUTSINMA, KATSINA STATE, NIGERIA
}

\author{
${ }^{1}$ Suleiman, U.F. and Ibrahim, S. \\ Department of Biological Sciences, Bayero University, Kano \\ Correspondence author: u.f.mindau65@gmail.com, +2347060807062
}

ABSTRACT

The abundance and distribution of phytoplankton algae in Zobe Reservoir was studied from using (3) sampling stations for a period of eight (8) months. The water was also analysed for Physicochemical attributes which includes Temperature, pH, Dissolved Oxygen, Biological Oxygen Demand, Nitrate-Nitrogen, Phosphate-Phosphorus, Total Dissolved Solids, Transparency and Electrical Conductivity using standard methods. Results showed that the values of physicochemical parameters recorded were of a typical tropical region. Station ' $B$ ' (middle) has highest number of organisms (284 org/I), followed by station ' $C$ ' (221 org/I), the least was recorded in station 'A' (162 org/I). Physicochemical attributes did not vary significantly among the stations. Four (4) classes of algae were identified which were dominated by Chlorophyta 386(57.87\%), followed by Cyanophyta 126 (18.89\%), and the least was Bacillariophyta 47(7.05\%) represented byTabellaria flocculosa. There were generally high number of algal organisms (Chlorophyta, Cyanophyta, Euglenophyta and Bacillariophyta) observed during the dry season than in the wet season. However, Spirogyra sp.had the highest number of occurrence in all stations (204 org/I) followed by Euglena sp. (109 org/I)and the least was Oscillatoria agardhii $(22$ org/I). There was positive significant correlation $(P<0.05)$ between algae and physicochemical attributes of the reservoir. The study showed that the reservoir was not polluted and the water is safe for domestic use since the number of harmful algal cells recorded were relatively low which were within the standardof World Health Organization for safe water (WHO, 2003).

Keywords: Phytoplankton, Zobe, Reservoir, Pollution, Cyanophyta.

\section{INTRODUCTION}

Water constitutes part of the dynamic aquatic life supporting system in which organic and inorganic constituents are dissolved or suspended and in which a wide variety of organisms live and interact with each other (Awah, 2008). In addition, water bodies provide valuable ecosystem services, such as water supply, food production, recreation and aesthetics. Having it available in sufficient quantity and quality contributes to the maintenance of health. Anthropogenic activities have been found to deteriorate surface waters and impair their basic use through the process of pollution (Chukwuet al., 2008).

Plankton is a collective term used to describe all those organisms whose power of movement is insufficient to prevent them from being moved by water currents. The Plankton can be classified in different ways, this include whether they are true or false plankton, their nutritional requirements (phytoplankton and zooplankton), their size, their environments, and their life history (Rabiuet al.,2014).
Planktons are used in various ways as indicators of water quality. The quantity of algae essentially determines the eutrophic level and quality of the water (Sarwade and Kamble, 2014). Drinking water supply, recreational activities and fisheries can be impaired by high phytoplankton biomass. Therefore, water quality management has to bemonitored and phytoplankton content in order, for instance to come up with preventive measures such as aeration to prevent fish kills during the decay of the planktonic biomass (Sharma, 2013).

According Ibrahim and Nafi'u (2017)phytoplankton have forlong been used as effective bio-indicators of eutrophic water that is sensitive to environmental changes, the rate of production of phytoplankton is determined by a host of environmental parameters like physicochemical properties of the water and soil, meteorological characteristics of the region, morphometric and hydrographic features of the water body. 
Special Conference Edition, November, 2019 According to Zaky (2015) the quality of any water resource is measured in the form of its physicochemical parameters. The physicochemical properties of water affect the quality of that water and its biological diversity. The changes in the physicochemical parameters tend to change the living conditions, especially in the number, diversity and distribution of the biota of that ecosystem. Fluctuations in physicochemical factors adversely affect the organisms, limiting their production and interfering with the physiological processes which reduce their ability to compete with other populations within the environment (Sharma, 2013).

The effect of physical factors such as light and heat are of great significance as they are solely responsible for certain phenomena such as thermal stratification, chemical stratification, diurnal and seasonal variations in the distribution and quality of planktons and other aquatic organisms. Interaction between physicochemical and biological factors were observed in the water bodies (Ibrahim, 2009; Sarwade and Kamble, 2014). The aim of this research is to determine the Spatial and Temporal Patterns of Phytoplankton Composition in Zobe Reservoir.

\section{MATERIALS AND METHODS \\ Study Area}

Zobe reservoir (Figure 1) is located in Dutsinma local government area $\left(12^{\circ} .238 \mathrm{~N} 7^{\circ} .229 \mathrm{E}\right.$.) of Katsina state in northern Nigeria. It is an earth filled structure with a height of $19 \mathrm{~m}$ and a total length of $2,750 \mathrm{~m}$. The reservoir has storage capacity of 179Mca and was divided into sites ( $A, B$ and $C$ ).

Where:

Site A $\left(12^{\circ} .367 \mathrm{~N}, 7^{\circ} 494 \mathrm{E}\right)$ is the outlet (spill way) of the dam, where human activities (swimming) take place during the dry season.

Site $B\left(12^{\circ} .366 \mathrm{~N}, 7^{\circ} .542 \mathrm{E}\right)$ is where there are agricultural activities (irrigation).

Site $\mathrm{C}(12.366 \mathrm{~N}, 7.461 \mathrm{E})$ is where there are less anthropogenic activities.

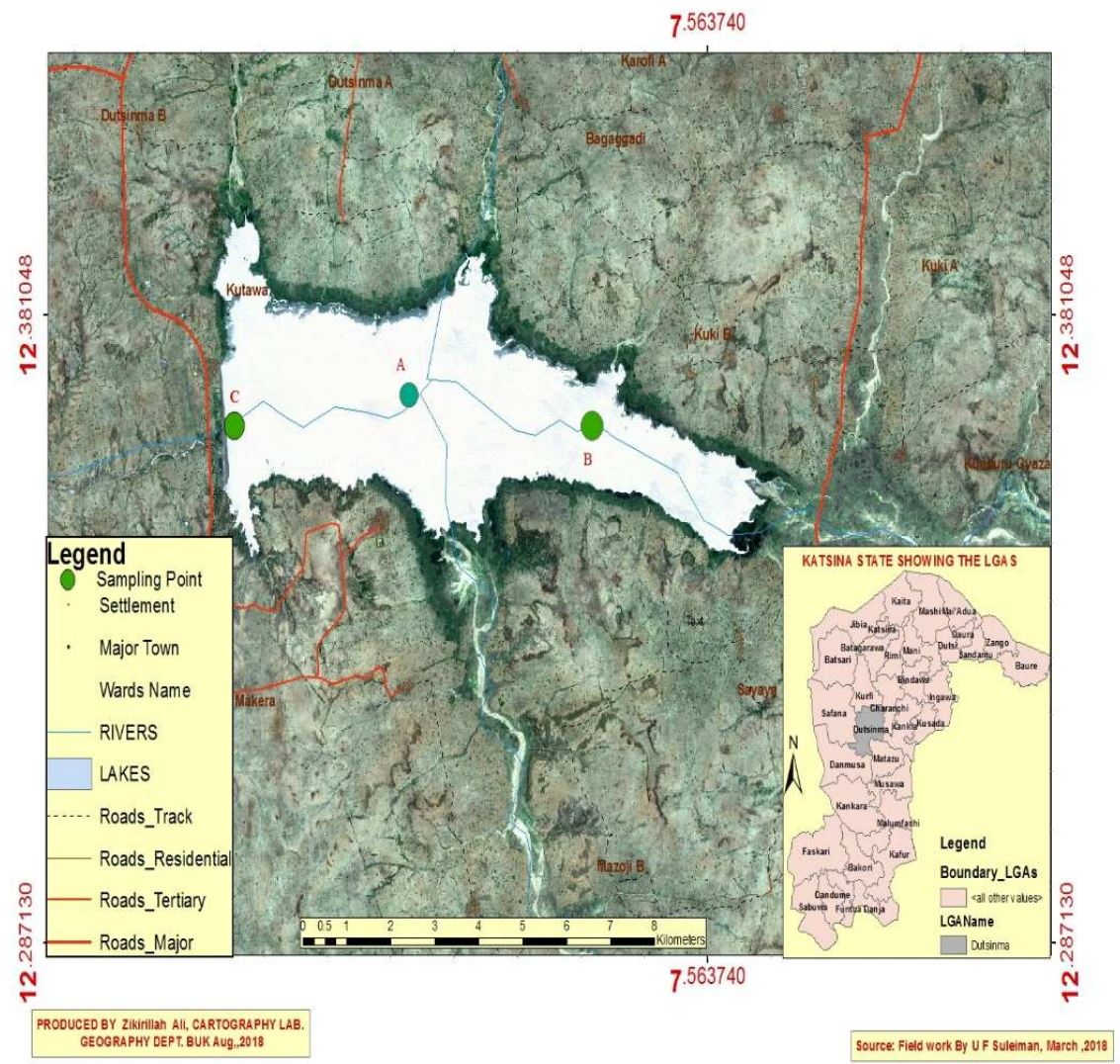

Figure 1: Map of Zobe Reservoir, Katsina, Showing Marked Sampling Sites (Source: Cartography Lab. Bayero University, Kano, 2018) 
Special Conference Edition, November, 2019 Sample Collection

Water samples were collected on fortnight basis between 8:00 and 10:00am from March to October, 2018 (APHA, 2010).Surface water Temperature, $\mathrm{pH}$, Electrical Conductivity and Total Dissolved Solids, were measured using calibrated digital multi-parameter water proof multipurpose HANNAH instrument (HI9813-6) by dipping it below the water and taking readings after it stabilizedas described by the manufacturers(APHA, 1999).Dissolved Oxygen was determined using Dissolved Oxygen Meter (JPB-607A model)as described by APHA (1999). Biological Oxygen Demand $\left(\mathrm{BOD}_{5}\right)$ was determined after 5 days of sample incubation as described by APHA (1999). The Nitrate-Nitrogen was determined using Nitrate Test Kit (ISO9001) according to the Manufacturer's instruction. Phosphorus-phosphate $\left(\mathrm{PO}_{4}{ }^{-3}\right)$ was measured using API Phosphate Test Kit(1595-01-0806, 1575-02-1504), in accordance with the manufacturers manual. The planktons were sampled with the aid of plankton net (with a fine mesh aperture, 20-60 $\mu \mathrm{m}$, with a small bottle container of $50 \mathrm{~cm}^{3}$ capacity attached to its narrow end). The water sample collected at each site was carefully emptied into a dark screw capped sample bottle. For preservation, 4\% formalin was added and transported to the Aquarium Laboratory of Biological Sciences Department, Bayero University, Kano, using a cooler flask. The sample bottles we real ways rinsed with distilled water in between samples to avoid contamination(Jason, 2012). The volume of the water that passed through the net was then estimated by using a formula (APHA, 2005) as follows:

$\mathrm{V}=\pi r^{2} \mathrm{~d}$

Where:

$\Pi=3.142$

$\mathrm{V}=$ volume of water filtered through the net,

$r=$ radius of the mouth of the net and

$\mathrm{d}=$ length of the haul

\section{Statistical Analysis}

Two way analysis of variance (ANOVA) was used to compare the means of various physicochemical parameters and planktons between months.Tukey's multiple comparison procedures were used to make comparisons among columns. These analyses were carried out using GraphPadinStat software (version 2.0). Canonical correspondence analysis (CCA) was used for correlations, to test the relationship between various parameters, which was done using XLSTAT (2018).

\section{RESULTS}

The phytoplankton phyla identified include Cyanophyta, Chlorophyta, Euglenophyta and
Bacillariophyta. Four Phytoplankton phyla were recorded, they were dominated by Chlorophyta then Cyanophyta followed by Euglenophyta and Bacillariophyta (Table 1). Station 'B' has highest organisms(284 org/l), followed by station ' $C$ ' (221 org/l), the least being station 'A' (162 org/l) Physicochemical attributes did not vary significantly among the stations. Among the Four groups of phytoplanktons were identified as Chlorophyta, Cyanophyta, Bacillariophyta and Euglenophyta. Comparatively, Chlorophyta was the dominating group with 386(57.87\%)organisms, followed by Cyanophyta,126(18.89\%), with poor representation of Bacillariophyta,47(7.05\%) and was only represented by Tabellaria flocculosa (Table 2). It was also observed that, algae were recorded in higher densities in the dry season than in the rainy season. The relatively high Chlorophyta algal cell recorded during the period of study could be due to increase in nutrient content of the reservoir leading to the development of phytoplankton. Euglenophyta and Bacillariophyta were poorly represented in this study (Table 2).

The results obtained for the physico-chemical parameters indicated that Temperature, $\mathrm{pH}$, Transparency, Electrical Conductivity, Total Dissolved Solids, Dissolved Oxygen, Biological Oxygen Demand, Nitrate and Phosphate showed significant difference at $p<0.05$ (Table 3 and 4). Based on the canonical correspondence analysis Eigen value ranged from $0.000-0.052$, indicating strong correlation between $\mathrm{pH}$, Nitrate, Total Dissolved Solids, Electrical Conductivity and Phosphate with respect to all of the stations. Similarly Temperature and Dissolved Oxygen showed normal correlation while Transparency and Biological Oxygen Demand had weak correlation (figure 2).

\section{Correlations between the physicochemical parameters of Zobe Reservoir}

Based on the Ordination of canonical correspondence analysis (CCA), the group environmental bi-plot shows the relations of the groups and environmental variables with the ordination axis. In the graph, environmental factors are indicated by the line, length of line represents the degree of relationship between sample plots and the distribution of environmental factors. The length of the arrow indicates the relative importance of the environmental variable in determining the axis. The positions of the group's centers (points) along the ordination axis represent their respective optima along the environmental gradient. 
Special Conference Edition, November, 2019

In Zobe reservoir, The group environmental correlation with axis correlated well with D.O, $\mathrm{BOD}_{5}$, water temperature, transparency, TDS,

EC and phosphate-phosphorous at $\mathrm{P}<0.05$

(Figure 2).

Table 1: Mean Number of Phytoplankton in Zobe Reservoir Recorded Between March and October, 2018

\begin{tabular}{|c|c|c|c|c|}
\hline \multirow[t]{2}{*}{ Months } & \multicolumn{4}{|c|}{ Phytoplanktons Phyla } \\
\hline & $\begin{array}{l}\text { Chlorophyta } \\
\text { means } \pm S D\end{array}$ & $\begin{array}{l}\text { Bacillariophyta } \\
\text { means } \pm S D\end{array}$ & $\begin{array}{l}\text { Euglenophyta } \\
\text { means } \pm S D\end{array}$ & $\begin{array}{l}\text { Cyanophyta } \\
\text { means } \pm S D\end{array}$ \\
\hline MARCH & $8.28 \pm 0.68$ & $14.00 \pm 5.29$ & $18.00 \pm 4.00$ & $8.00 \pm 9.17$ \\
\hline APRIL & $7.38 \pm 0.91$ & $12.33 \pm 7.10$ & $5.67 \pm 4.93$ & $6.00 \pm 5.29$ \\
\hline MAY & $4.50 \pm 1.00$ & $3.33 \pm 0.58$ & $11.00 \pm 2.65$ & $1.33 \pm 1.53$ \\
\hline JUNE & $4.20 \pm 0.96$ & $0.00 \pm 0.00$ & $5.67 \pm 1.16$ & $1.33 \pm 0.58$ \\
\hline JULY & $1.53 \pm 0.25$ & $0.00 \pm 0.00$ & $3.00 \pm 1.00$ & $0.67 \pm 1.16$ \\
\hline AUGUST & $1.63 \pm 0.58$ & $0.33 \pm 0.58$ & $1.67 \pm 0.58$ & $0.67 \pm 1.16$ \\
\hline SEPTEMBER & $1.80 \pm 0.50$ & $0.00 \pm 0.00$ & $3.33 \pm 0.58$ & $1.33 \pm 1.53$ \\
\hline OCTOBER & $3.20 \pm 1.67$ & $1.00 \pm 1.00$ & $5.00 \pm 2.00$ & $1.67 \pm 1.53$ \\
\hline
\end{tabular}

Table 2 : Occurrence and Relative Abundance of Phytoplankton Species at Sampling Stations of Zobe Reservoir (March-October 2018)

\begin{tabular}{|c|c|c|c|c|c|}
\hline \multirow[b]{2}{*}{ Taxon } & \multicolumn{3}{|c|}{ Sampling stations } & \multirow[b]{2}{*}{ Total(Org/L) } & \multirow[b]{2}{*}{ Total(Org/Taxon) } \\
\hline & $A$ & B & C & & \\
\hline \multicolumn{6}{|l|}{ Chlorophyta } \\
\hline Oedogonium sp. & 5 & 34 & 15 & 54 & \\
\hline Haematococcus sp. & 9 & 8 & 14 & 31 & \\
\hline Volvox sp. & 6 & 23 & 3 & 32 & 385 \\
\hline Spirogyra sp. & 60 & 70 & 73 & 203 & \\
\hline Scenedesmus sp. & 21 & 20 & 24 & 65 & \\
\hline \multicolumn{6}{|l|}{ Cyanophyta } \\
\hline Cylindrispermupsis sp. & 12 & 26 & 13 & 51 & \\
\hline Anabaena sp. & 15 & 19 & 19 & 53 & 126 \\
\hline Oscillatoria agardhii & 2 & 19 & 1 & 22 & \\
\hline \multicolumn{6}{|l|}{ Euglenophyta } \\
\hline $\begin{array}{l}\text { Euglena sp. } \\
\text { Bacillariophyta }\end{array}$ & 24 & 46 & 39 & 109 & 109 \\
\hline Tabellaria flocculosa & 8 & 19 & 20 & 47 & 47 \\
\hline Total(Org/L) & 162 & 284 & 221 & 667 & 667 \\
\hline
\end{tabular}

Table 3. Monthly Mean Values and Standard Deviation of Physicochemical Parameters of Zobe Reservoir from March to October, 2018

\begin{tabular}{lcclcc}
\hline MONTHS & Temp. $\left({ }^{\circ} \mathbf{C}\right)$ & $\mathbf{p H}$ & EC $(\boldsymbol{\mu S} / \mathbf{c m})$ & $\mathbf{D O}(\mathbf{m g} / \mathbf{L})$ & $\mathbf{B O D}_{\mathbf{5}}(\mathbf{m g} / \mathbf{L})$ \\
\hline MARCH & means & means & means & means & means \\
APRIL & $\pm S D 26.23 \pm 3.21^{\mathrm{b}}$ & $\pm S D 7.29 \pm 0.15^{\mathrm{c}}$ & $\pm S D 73.33 \pm 5.77^{\mathrm{a}}$ & $\pm S D 8.91 \pm 0.29^{\mathrm{b}}$ & $\pm S D 4.01 \pm 0.39^{\mathrm{a}}$ \\
MAY & $28.32 \pm 0.08^{\mathrm{c}}$ & $6.97 \pm 0.19^{\mathrm{c}}$ & $70.00 \pm 0.00 \mathrm{a}$ & $6.09 \pm 1.33^{\mathrm{b}}$ & $3.45 \pm 0.56^{\mathrm{b}}$ \\
JUNE & $28.22 \pm 0.66^{\mathrm{c}}$ & $6.53 \pm 0.22^{\mathrm{c}}$ & $73.33 \pm 5.77^{\mathrm{a}}$ & $6.61 \pm 0.48^{\mathrm{b}}$ & $3.09 \pm 0.11^{\mathrm{b}}$ \\
JULY & $24.36 \pm 0.18^{\mathrm{b}}$ & $6.52 \pm 0.20^{\mathrm{c}}$ & $73.33 \pm 5.77^{\mathrm{a}}$ & $8.57 \pm 0.78^{\mathrm{c}}$ & $6.38 \pm 0.19^{\mathrm{b}}$ \\
AUGUST & $24.38 \pm 0.21^{\mathrm{b}}$ & $6.63 \pm 0.52^{\mathrm{c}}$ & $153.33 \pm 2.91^{\mathrm{b}}$ & $9.02 \pm 0.26^{\mathrm{a}}$ & $7.24 \pm 0.11^{\mathrm{c}}$ \\
SEPTEMBER & $21.76 \pm 1.00^{\mathrm{a}}$ & $6.62 \pm 1.28^{\mathrm{b}}$ & $60.00 \pm 3.64^{\mathrm{b}}$ & $9.76 \pm 0.55^{\mathrm{a}}$ & $7.99 \pm 0.86^{\mathrm{c}}$ \\
OCTOBER & $21.95 \pm 0.47^{\mathrm{b}}$ & $7.27 \pm 0.15^{\mathrm{b}}$ & $32.00 \pm 3.46^{\mathrm{c}}$ & $8.73 \pm 0.80 \mathrm{c}$ & $7.12 \pm 0.95^{\mathrm{c}}$ \\
\hline
\end{tabular}

Means having same superscripts along columns are the same at $P<0.05$ using SD 
Special Conference Edition, November, 2019

Table 4: Monthly Mean Values and Standard Deviation of Physicochemical Parameters of Zobe Reservoir from March to October, 2018

\begin{tabular}{|c|c|c|c|c|}
\hline MONTHS & $\begin{array}{c}\text { TDS } \\
(\mathrm{mg} / \mathrm{L})\end{array}$ & $\begin{array}{c}\text { Transparency } \\
\text { (cm) }\end{array}$ & Nitrate $(\mathrm{mg} / \mathrm{L})$ & $\begin{array}{l}\text { Phosphate } \\
\text { (mg/L) }\end{array}$ \\
\hline MARCH & $\begin{array}{c}\text { means } \\
\pm \mathrm{SD} 58.14 \pm 2.85^{\mathrm{b}}\end{array}$ & $\begin{array}{c}\text { means } \\
\pm \mathrm{SD} 10.51 \pm 1.55^{\mathrm{b}}\end{array}$ & $\begin{array}{c}\text { means } \\
\pm \mathrm{SD} 0.06 \pm 0.04^{\mathrm{c}}\end{array}$ & $\begin{array}{l}\text { means } \pm S D \\
0.33 \pm 0.51^{b}\end{array}$ \\
\hline APRIL & $55.99 \pm 0.34^{\mathrm{b}}$ & $11.47 \pm 1.29^{b}$ & $0.14 \pm 0.04^{c}$ & $0.39 \pm 0.46^{b}$ \\
\hline MAY & $54.06 \pm 1.70^{\mathrm{b}}$ & $10.42 \pm 0.40^{\mathrm{b}}$ & $0.09 \pm 0.02^{c}$ & $0.10 \pm 0.05^{b}$ \\
\hline JUNE & $56.30 \pm 0.26^{b}$ & $10.04 \pm 0.49^{b}$ & $0.12 \pm 0.01^{c}$ & $0.10 \pm 0.01^{\mathrm{b}}$ \\
\hline JULY & $109.11 \pm 54.34^{\mathrm{a}}$ & $6.84 \pm 0.81^{\mathrm{b}}$ & $0.24 \pm 0.09^{b}$ & $0.11 \pm 0.02^{c}$ \\
\hline AUGUST & $50.89 \pm 24.06^{a}$ & $5.84 \pm 0.96^{b}$ & $0.25 \pm 0.05^{b}$ & $0.14 \pm 0.06^{c}$ \\
\hline SEPTEMBER & $28.74 \pm 2.04^{\mathrm{a}}$ & $5.55 \pm 0.25^{b}$ & $0.24 \pm 0.04^{b}$ & $0.17 \pm 0.06^{c}$ \\
\hline OCTOBER & $130.00 \pm 6.08^{\mathrm{a}}$ & $8.89 \pm 0.27^{b}$ & $0.43 \pm 0.08^{c}$ & $0.19 \pm 0.03^{c}$ \\
\hline
\end{tabular}

Means having same superscripts along columns are the same at $P<0.05$.

Table 5: Seasonal Mean Value and Standard Deviation of Physicochemical Parameters of Zobe Reservoirs from March to October, 2018

\begin{tabular}{lll}
\hline PARAMETERS & DRY SEASON & RAINY SEASON \\
\hline Temperature $\left({ }^{\circ} \mathrm{C}\right)$ & means \pm SD & means \pm SD \\
$\mathrm{pH}$ & $26.77 \pm 1.91$ & $23.11 \pm 1.45$ \\
$\mathrm{EC}(\mu \mathrm{S} / \mathrm{cm})$ & $6.97 \pm 0.32$ & $6.01 \pm 1.14$ \\
$\mathrm{DO}(\mathrm{mg} / \mathrm{L})$ & $94.99 \pm 4.58$ & $79.67 \pm 2.04$ \\
$\mathrm{BOD}_{5}(\mathrm{mg} / \mathrm{L})$ & $7.39 \pm 1.28$ & $9.01 \pm 0.53$ \\
$\mathrm{TDS}^{(\mathrm{mg} / \mathrm{L})}$ & $3.69 \pm 0.51$ & $7.18 \pm 0.66$ \\
Transparency $(\mathrm{cm})$ & $74.55 \pm 3.01$ & $61.26 \pm 4.06$ \\
Nitrate, $\mathrm{NO}_{3}-\mathrm{N}(\mathrm{mg} / \mathrm{L})$ & $10.32 \pm 1.07$ & $7.07 \pm 2.06$ \\
Phosphate, $\mathrm{PO}_{4}-\mathrm{P}(\mathrm{mg} / \mathrm{L})$ & $0.18 \pm 0.17$ & $0.21 \pm 0.06$ \\
\hline
\end{tabular}

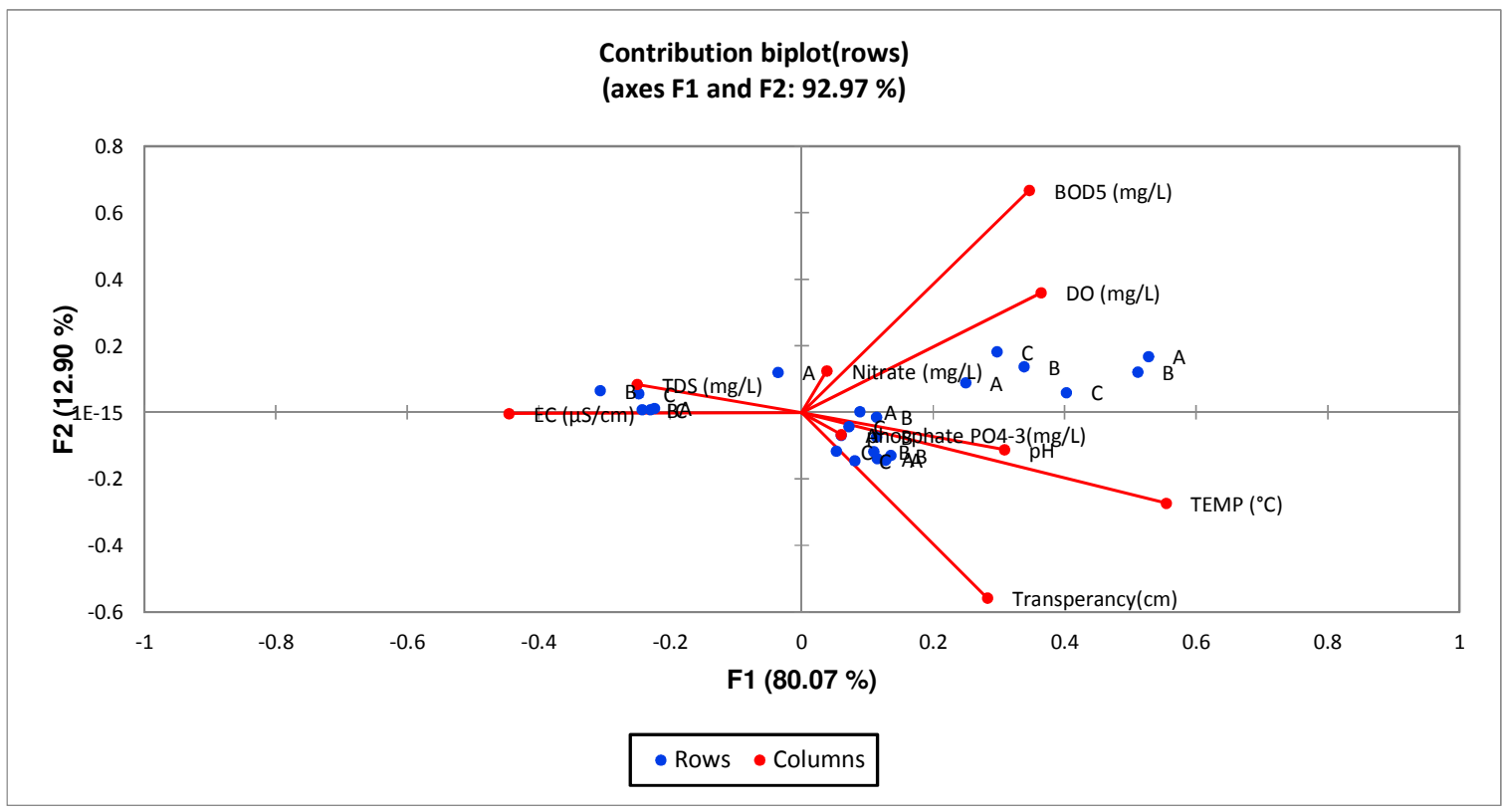

Figure 2: Correlations Between Physicochemical Parameters and Stations of Zobe Reservoir (March-October, 2018) 


\section{REFERENCES}

Abdullahi, B.A. and Indabawa, L.I. (2005). Ecology of freshwater Phytoplankton of River Hadejia, Jigawa State. Biological and Environmental Science Journal for the Tropics, 1(2): 141-145.

Abubakar, M.M. (2007). The Phytoplankton Community of a Semi-and lake, Nguru Lake. Kano Journal for Science Education, 40(1):16-21.

Anyam, R.W. (1980). Some aspects of the freshwater ecology of two man-made lakes nearZaria, Nigeria. Unpublished M.Sc. Thesis,Ahmadu Bello University, Zaria

APHA (1999). Standard Methods of Examination of Water and Wastewater. American Public Health Association: 20th edition Washington D.C., 1076 p.

APHA (2010). Standard Methods for the Examination of Water and Wastewater, $20^{\text {th }}$ ed.Clescerilsgreenbery $A B, \&$ Eaton, AD (Eds), AmericanPublic health Associated, Washington DC

APHA (2005).Standard Methods for the Examination of Water and Wastewater, $21^{\text {st }}$ edition, eds. Eaton, A.D., Clescer, L.S., Rice, E.W. and Greenberg, A.E. Port City Press, Baltimore, MA, USA, 10: 4-100.

Awah, T.M. (2008). Water Pollution of the NkoupDam System and its environmental impact in Foumbot, An Agricultural Town in Western Cameroon. Ph.D Thesis, University of Yaounde I, Cameroon. 209p.

Bhivgade SW, Taware AS, Salve US, Dhaware AS (2010). Limnological studies on some aspects Of Nagzari Tank, Ambajogai, District Beed, Maharashtra. J. Aquat. Biol. 25(2): $4-7$.

Chukwu, O.,Segi, S. andAdeoye, P.A. (2008). Effect of Car-wash effluent on the Quality of Receiving Stream. J. Eng. Appl. Sci. 3:607-610.

Edema, C.U.Ayeni, J.O. and Aruoture, A. (2002). Someobservations of the Okhuo River, Nigeria Journal of Aquatic Sciences, 17 (2): $145-149$.

Ezra, A.G, Abdulhameed, A and Sindama, A (2008). Aspects of Physico-Chemical Properties of Shadawanka River, Bauchi, Northeast Nigeria. International Journal of natural and Applied Sciences, 4(4):441-444.

Ibrahim, S. and Nafi'u, S. A. (2017). Phytoplankton as Indicators of Water
Quality in Thomas Dam, Dambatta, Kano State, Nigeria,Dutse Journal of Pure and Applied Sciences (DUJOPAS), 3(1): 119-133.

Ibrahim, S. (2009). A survey of Zooplankton diversity of Challawa Dam, Kano and evaluation of some of its PhysicoChemical conditions, Bayero Journal of Pure and Applied Sciences(BAJOPA S), 2(1): 19-26.

Jason, D. J. (2012). Standard Operating Procedures for Surface Water Quality Sampling.ADEQ, 1110 W. Washington St., Phoenix, AZ 85007.36-69p.

Kadiri, M.O. (1993). Seasonal Changes in Phytoplankton Biomass of Shallow Tropical Reservoir. Nigerian Journal of Botany, 6:167- 175.

Kemdirim, E.C. (2000). Dial rhythm of plankton and physico-chemical parameters in Kangimi reservoir, Kaduna State Nigeria. Journal of Aquatic Sciences, 15:35 - 39.

Kilhem, P. and Hecky, R. (1988).Comparative ecology of marine and fresh water phytoplankton: Immunological Oceanography, 33:776-795.

Lamai, S.L. and KOLO, R.J. (2003). Biodiversity in DanZaria Dam, Niger state, Nigerian Journal ofAquatic Sciences, 18(2): 140 148.

Rabiu, M.K., Mohammad, M.A. and Muhammad, L.B. (2014). The Plankton as Indicators of Water Quality in Kusalla Reservoir: A Shallow Man Made Lake, International Journal of Advanced Academic Research I Sciences, Technology \& Engineering, 9(3): 12-15.

Sarwade, A. B. and Kamble, N. A. (2014). Plankton diversity in Krishna Dam, Sangli, Maharashtra, Journal of Ecology and the Natural Environment, 6(4):174181. https://doi.org/10.5897/JENE2013.0409

Sharma, D. K. (2013). Correlation between physico-chemical parameters and phytoplankton of Tighra reservoir, Gwalior, International Journal of Science and Nature, 4(1): 90-95.

World Health Organization (2003). Guidelines for Safe Recreational Water Environment. Volume 1: Coastal and Fresh Waters, Geneva, 1-33p.

Zaky, S. K. (2015). Study of phytoplanktonin relation to physico- chemical properties of a drainage in Kakuri industrial base settlement in Kaduna, Nigeria, Elsevier Ltd., 1O(2): 6-12. 